\title{
Kontribusi Pajak Daerah Dan Retribusi Daerah Terhadap Pendapatan Asli Daerah Di Kabupaten Barru
}

\author{
A. Imam Zulfikar ${ }^{1}$, Abdul Rahman² \\ ${ }^{1}$ Fakultas Ekonomi STIE Wira Bhakti Makassar \\ ${ }^{2}$ Fakultas Ekonomi STIE Wira Bhakti Makassar \\ Email : Imamimam.113@gmail.com
}

direvisi: 18 Januari 2019 dipublikasikan: 31 Januari 2019

\begin{abstract}
Abstrak
Penelitian ini bertujuan untuk mengetahui besarnya kontribusi Pajak Daerah terhadap Pendapatan Asli Daerah di Kabupaten Barru, dan untuk mengetahui besarnya kontribusi Retribusi Daerah terhadap Pendapatan Asli Daerah di Kabupaten Barru, serta untuk mengetahui besarnya kontribusi Pajak Daerah dan Retribusi Daerah terhadap Pendapatan Asli Daerah di Kabupaten Barru. Jenis Penelitian ini bersifat deskriptif. Metode dan teknik pengumpulan data yang digunakan dalam penelitian ini adalah dokumentasi dan wawancara, Selanjutnya data di analisis dengan menggunakan analisis persentase. Hasil penelitian ini menunjukkan bahwa Kontribusi Pajak Daerah terhadap Pendapatan Asli Daerah di Kabupaten Barru tahun 2013-2017 tergolong kecil dengan nilai persentase 12,82\% yang disebabkan oleh pengetahuan dan pemahaman para wajib pajak yang masih minim dan petugas pajak yang ditunjuk atau mengawasi dan menangani kurang maksimal yang di dukung pula dengan sistem pemungutan pajak yang menganut sistem self assesment. sementara Kontribusi Retribusi Daerah terhadap Pendapatan Asli Daerah di Kabupaten Barru tahun 2013-2017 tergolong kecil dengan nilai persentase 17,34\% yang disebabkan oleh kurangnya penerimaan dari wajib Retribusi, serta sarana dan prasanana yang disediakan oleh pemerintah juga masih kurang sedangkan Kontribusi Pajak Daerah dan Retribusi Daerah terhadap Pendapatan Asli Daerah di Kabupaten Barru tahun 2013-2017 tergolong cukup dengan nilai persentase 30,06\%. Berdasarkan hasil analisis persentase bahwa dari ke empat sumber Pendapatan Asli Daerah, Lain-lain Pendapatan Asli Daerah yang Salah yang mempunyai kontribusi yang cukup besar terhadap Pendapatan Asli Daerah dengan persentase sebesar 48, 38\% dan memiliki perkembangan yang baik dengan rata-rata perkembangan yaitu 72,20\% yang tergolong besar, adapun yang mempunyai kontribusi yang kecil yaitu Pajak Daerah dengan persentase 12,82\% dan rata-rata perkembangannya sebesar 43,97\% yang tergolong cukup besar, serta kontribusi Retribusi sebesar 17,34\% dengan rata-rata perkembangan sebesar 30,81\% yang tergolong cukup.
\end{abstract}

Kata Kunci : Kontribusi Pajak Daerah, Retribusi Daerah, Pendapatan Asli Daerah 


\title{
Sentralisasi Volume 8 (1) : Hal 18 - 32 | 2019 kontribusi pajak daerah dan retribusi daerah... DOI: https://doi.org/10.33506/sl.v8i1.384
}

A.Imam Zulfikar

\begin{abstract}
Abstrak
This study aims to determine the magnitude of the contribution of Regional Taxes to Regional Original Revenue in Barru Regency, and to determine the contribution of Regional Levies to Regional Original Revenues in Barru District, and to determine the contribution of Regional Taxes and Regional Levies to Regional Original Revenues in Barru Regency. This type of research is descriptive. The methods and data collection techniques used in this study are documentation and interviews, then the data is analyzed using percentage analysis. The results of this study indicate that the Regional Tax Contribution to Regional Original Revenue in Barru Regency in 2013-2017 is relatively small with a percentage of $12.82 \%$ due to the minimal knowledge and understanding of taxpayers and designated tax officers or overseeing and handling less the maximum that is supported also by the tax collection system that adheres to the self assessment system. while the contribution of regional levies to regional original income in Barru Regency in 2013-2017 is small, with a percentage value of $17.34 \%$ due to lack of revenue from levies, and facilities and infrastructure provided by the government are still lacking while local tax contributions and levies Regions of Regional Original Revenue in Barru Regency in 2013-2017 are classified as sufficient with a percentage value of 30.06\%. Based on the results of the percentage analysis that from the four sources of Regional Original Revenue, Others Incorrect Local Revenue that has a considerable contribution to Regional Original Income with a percentage of $48.38 \%$ and has a good development with a development average of $72,20 \%$ are classified as large, while those that have a small contribution are Regional Tax with a percentage of $12.82 \%$ and the average development of $43.97 \%$ which is quite large, and contribution of Retribution is $17.34 \%$ with the average development amounting to $30.81 \%$ which is considered sufficient.
\end{abstract}

Keywords: Regional Tax Contribution, Regional Retribution, Regional Original Income

\section{Pendahuluan}

Pembangunan pada hakikatnya adalah suatu proses perubahan secara terus menerus yang merupakan kemajuan dan perbaikan ke arah yang ingin dicapai. Dengan demikian pembangunan bukanlah suatu proses yang sekali jadi akan tetapi memerlukan jangka waktu tertentu untuk menyelesaikannya. Keberhasilan suatu pembangunan pada dasarnya ditentukan oleh tersedianya dana yang cukup memadai dan tergantung pula pada pengelolaan pandapatan daerah.

Salah satu upaya untuk meningkatkan penerimaan daerah antara lain melalui sektor Pajak Daerah dan Retribusi Daerah. Pajak Daerah merupakan iuran wajib yang dilakukan oleh orang pribadi atau badan kepada daerah tanpa imbalan langsung yang seimbang, yang dapat dipaksakan berdasarkan undang-undang yang berlaku dan digunakan untuk membiayai penyelenggaraan pemerintahan daerah dan pembangunan 


\section{Sentralisasi Volume 8 (1) : Hal 18 - 32 | 2019}

kontribusi pajak daerah dan retribusi daerah... DOI: https://doi.org/10.33506/sl.v8i1.384

A.Imam Zulfikar

daerah. Sementara Retribusi Daerah merupakan pungutan daerah sebagai pembayaran atas jasa atau perizinan tertentu yang khusus disediakan dan/atau diberikan oleh pemerintah daerah untuk kepentingan orang pribadi atau badan. Untuk itu dengan mengetahui peran dari Pajak Daerah dan Retribusi Daerah terhadap penerimaan daerah dalam hal ini Pendapatan Asli Daerah maka dibutuhkan peran serta masyarakat dalam bentuk kesadaran dan kepedulian untuk membayar Pajak, baik Pajak Daerah maupun Retribusi Daerah.

Setelah pemerintah pusat mengeluarkan Undang-Undang Nomor 22 Tahun 1999 dan diperbaharui dengan Undang-Undang Nomor 32 Tahun 2004 tentang Perimbangan Keuangan antara Pemerintahan Daerah yang terfokus pada otonomi daerah dan UndangUndang Nomor 25 tahun 1999 yang diperbaharui dengan Undang-Undang Nomor 33 Tahun 2004 tentang perimbangan keuangan antara pemerintah pusat dan daerah, maka pemerintah daerah diberi kekuasaan yang lebih besar untuk mengatur anggaran daerahnya. Untuk mendukung pelaksanaan otonomi yang maksimal pemerintah mengeluarkan kebijaksanaan di bidang penerimaan daerah yang berorientasi pada peningkatan kemampuan daerah untuk membiayai urusan rumah tangganya sendiri dan diprioritaskan pada penggalian dana mobilisasi sumber-sumber daerah. Sumber Pendapatan Daerah menurut Pasal 6 Undang-Undang Nomor 33 Tahun 2004 adalah: (1). Pendapatan Asli Daerah (PAD), (2). Dana Perimbangan, dan (3). Lain-lain Pendapatan Daerah yang Sah.

Pendapatan Asli Daerah (PAD) merupakan sumber pendapatan daerah yang secara bebas dapat digunakan oleh masing-masing daerah untuk menyelenggarakan pemerintahan dan pembangunan daerah. Tapi pada kenyataannya kontribusi Pendapatan Asli Daerah terhadap Pendapatan dan Belanja Daerah masih kecil. Selama ini dominasi sumbangan pemerintah pusat kepada daerah masih besar. Oleh karena itu, untuk mengurangi ketergantungan kepada pemerintah pusat, pemerintah daerah perlu berusaha meningkatkan Pendapatan Asli Daerah (PAD) yang salah satunya dengan penggalian potensi daerah. Kabupaten Barru merupakan salah satu Kabupaten yang ada di propinsi Sulawesi Selatan. Guna meningkatkan kemampuannya dalam bidang 


\section{Sentralisasi Volume 8 (1) : Hal 18 - 32 | 2019 kontribusi pajak daerah dan retribusi daerah... DOI: https://doi.org/10.33506/sl.v8i1.384}

pendanaan untuk pembangunan, Pemerintah Kabupaten Barru meningkatkan Pendapatan Asli Daerah (PAD) melalui Pajak Daerah dan Retribusi Daerah.

Pendapatan Asli Daerah dari tahun 2010-2012 berfluktuasi. Seperti yang telah diketahui bahwa ketika Pajak Daerah dan Retribusi Daerah naik maka Pendapatan Asli Daerah juga naik, namun berbeda halnya penerimaan Pajak Daerah dan Retribusi Daerah serta Pendapatan Asli Daerah di Kabupaten Barru pada tahun 2012 di mana Pajak Daerah dan Retribusi Daerah mengalami peningkatan tetapi penerimaan Pendapatan Asli Daerahnya menurun. adapun hal yang menyebabkan demikian karena penerimaan dari dua sumber Pendapatan Asli Daerah yaitu Hasil Pengelolaan Kekayaan Daerah yang dipisahkan dan Lain-Lain Pendapatan Asli Daerah yang Sah mengalami penurunan yang tidak mapu di imbangi oleh peningkatan dari Pajak Daerah dan Retribusi Daerah.

\section{Tujuan Penelitian}

Berdasarkan rumusan masalah yang telah dikemukakan maka tujuan penelitian ini adalah (1) Untuk mengetahui besarnya Kontribusi Pajak Daerah, Retribusi Daerah terhadap Pendapatan Asli Daerah di Kabupaten Barru.(2) Untuk mengetahui besarnya Kontribusi Pajak Daerah dan Retribusi Daerah terhadap Pendapatan Asli Daerah di Kabupaten Barru.

\section{Metode Penelitian}

Penelitian ini bersifat deskriptif yaitu menjelaskan dan menganalisis kontribusi Pajak Daerah dan Retribusi Daerah terhadap Pendapatan Asli Daerah pada Badan Pengelola Keuangan Daerah. Jenis data meliputi: Data kuantitatif yaitu data yang berbentuk angka seperti besarnya penerimaan pajak daerah dan retribusi daerah yang didapatkan oleh Badan Pengelola Keuangan Daerah pada Kabupaten Barru. Teknik pengumpulan data dalam penelitian ini adalah mengumpulkan dokumen yang ada pada Badan Pengelolaan Keuangan Daerah di Kabupaten Barru. Analisis data dilakukan dengan teknik analisis kontribusi. 


\section{Sentralisasi Volume 8 (1) : Hal 18 - 32 | 2019 kontribusi pajak daerah dan retribusi daerah... DOI: https://doi.org/10.33506/sl.v8i1.384}

A.Imam Zulfikar

\section{Teknik Pengumpulan Data}

Adapun teknik pengumpulan data yang digunakan dalam penelitian ini adalah sebagai berikut (1) Dokumentasi adalah mengumpulkan data berupa dokumen yang berhubungan dengan penelitian yang akan dilakukan dimana metode pengumpulan data ini berdasarakan pada dokumen-dokumen berupa data-data sekunder yang diperoleh dari dinas pendapatan kabupaten barru. (2) Wawancara adalah mengadakan pembicaraan secara langsung dengan pihak yang berkompeten yakni pimpinan, bagian keuangan dan pihak-pihak lain yang terkait dengan penelitian untuk mendapat respon/informasi mengenai hal yang akan diteliti dalam hal ini.

\section{Teknik Analisis Data}

Teknik analisis data yang digunakan dalam penelitian ini adalah analisis persentase. Analisis persentase yang digunakan untuk mengetahui besarnya kontribusi penerimaan Pajak Daerah dan Retribusi Daerah terhadap Pendapatan Asli Daerah di Kabupaten Barru, dengan menggunakan rumus yang dikemukakan oleh Sudjana (2001:205) yaitu:

$$
A=\frac{\mathrm{X}}{\mathrm{N}} \times 100 \%
$$

Dimana : A = Persentase penerimaan Pajak Daerah dan/atau Retribusi Daerah

$\mathrm{X}=$ Total penerimaan Pajak Daerah dan/atau Retribusi Daerah pada periode tertentu

$\mathrm{N}=$ Total penerimaan Pendapatan Asli Daerah pada periode tertentu.

$$
A_{1}=\frac{\mathrm{X}_{1}}{\mathrm{~N}} \times 100 \%
$$

Dimana : $\quad \mathrm{A}_{1}=$ Persentase kontribusi penerimaan Pajak Daerah

$\mathrm{X}_{1}=$ Total penerimaan Pajak Daerah pada periode tertentu

$\mathrm{N}=$ Total Pendapatan Asli Daerah pada periode tertentu 


\section{Sentralisasi Volume 8 (1) : Hal 18 - 32 | 2019 kontribusi pajak daerah dan retribusi daerah... DOI: https://doi.org/10.33506/sl.v8i1.384}

A.Imam Zulfikar

$$
A_{2}=\frac{X_{2}}{N} \quad x \quad 100 \%
$$

Dimana : $\quad A_{2}=$ Persentase kontribusi penerimaan Retribusi Daerah

$\mathrm{X}_{2}=$ Total penerimaan Retribusi Daerah pada periode tertentu

$\mathrm{N}=$ Total Pendapatan Asli Daerah pada periode tertentu

$$
A_{12}=\frac{X_{12}}{N} \times 100 \%
$$

Dimana : $\quad \mathrm{A}_{12}=$ Persentase kontribusi penerimaan Pajak Daerah dan Retribusi Daerah

$\mathrm{X}_{12}=$ Total penerimaan Pajak Daerah dan Retribusi Daerah pada periode tertentu

$\mathrm{N}=$ Total Pendapatan Asli Daerah pada periode tertentu

Selanjutnya untuk melihat hasil dari nilai kontribusi yang diperoleh, menurut Badan Pengelola Keuangan Daerah di Kabupaten Barru, maka disusun ukuran sebagai berikut:

\begin{tabular}{ll}
\hline Interval & Ukuran/kategori \\
\hline $80 \%-100 \%$ & Besar Sekali \\
$60 \%-79 \%$ & Besar \\
$40 \%-59 \%$ & Cukup Besar \\
$20 \%-39 \%$ & Cukup \\
$0 \%-19 \%$ & Kecil \\
\hline
\end{tabular}

\section{Hasil dan Pembahasan}

Perkembangan sumber-sumber Pendapatan Asli Daerah yang dikelolah oleh Badan Pengelola Keuangan Daerah Kabupaten Barru adalah (1) Pajak Daerah dengan sumber-sumber penerimaan dari 1) Pajak Hotel, 2) Pajak Restoran, 3) Pajak Hiburan, 4) Pajak Reklame, 5) Pajak Penerangan Jalan, 6) Pajak Galian Gol. C dan 7) Pajak BPHTB. (2) Retribusi Daerah dengan sumber-sumber penerimaan dari : 1) Ret. Pelayanan Kesehatan, 2) Ret. Pelayanan Kebersihan, 3) Ret. Biaya KTP, 4) Ret. 
Pelayanan Parkir, 5) Ret. Pelayanan Pasar, 6) Ret. Pengujian Kendaraan Bermotor, 7) Ret. Ketatausahaan, 8) Ret. Pemakaian Kekayaan daerah, 9) Ret. Jasa Grosir, 10) Ret. Terminal, 11) Ret. Tempat Rekreasi, 12) Ret. Izin Tempat Usaha, 13) Ret. Pangkalan Hasil Bumi dan Laut, 14) Ret. Tempat Daftar Perusahaan, 15) Ret. SIUP, 16) Ret. IMB, 17) Ret. Izin Gangguan, 18) Ret. Izin Trayek, 19) Ret. Telekomunikasi khusus, 20) Ret.Pengujian Kapal Perikanan. (3) Laba Hasil Usaha Daerah berupa Hasil Pengelolaan Kekayaan Daerah yang dipisahkan dengan sumber penerimaan dari 1) Bank BPD, 2) Laba BUMN, 3) Laba BUMD, 4) Perusahaan Setya Karya. (4) Lain-lain Pendapatan Yang Sah dengan sumber penerimaan dari: 1) Jasa Giro, 2) Pengambilan Dana Bergulir, 3) Sumbangan Pihak ke tiga, 4) Pendapatan Bungan Deposito, 5) Penerimaan Lain-lain.

Sumber penerimaan Pendapatan Asli Daerah seperti yang telah disajikan pada tabel 2, yang terdiri atas Pajak Daerah, Retribusi Daerah, Hasil Pengelolaan Kekayaan Daerah yang dipisahkan serta Lain-lain Pendapatan Asli Daerah yang Sah selama 5 tahun terakhir yaitu tahun 2013-2017, dapat diketahui bahwa perkembangan penerimaan Pendapatan Asli Daerah dari tahun ketahun mengalami fluktuasi, dapat dilihat pada tahun 2013 ke tahun 2014, perkembangan penerimaan Pendapatan Asli Daerah sebesar 57,63\% hal ini disebabkan oleh meningkat nya sumber-sumber Pendapatan Asli Daerah khususnya pada sumber Lain-lain Pendapatan Asli Daerah yang Sah sebesar 70,12\% yang disebabkan oleh meningkatnya penerimaan dari penerimaan lain-lain sebesar 93,44\%, tetapi disisi lain terjadi penurunan pada peneimaan Pajak Daerah sebesar 79,17\% yang disebabkan oleh menurunnya penerimaan dari Pajak Penerangan Jalan sebesar 88,77\%. Begitupun halnya pada tahuun 2016 ke tahun 2017 dimana perkembangan penerimaan Pendapatan Asli Daerah meningkat dari $(52,30) \%$ menjadi 44,61\% yang disebabkan oleh meningkatnya penerimaan Retribusi Daerah dari $21,91 \%$ menjadi 60,41\% terutama penerimaan sumber penerimaan Retribusi Daerah yaitu Retribusi Pelayanan Kesehatan dari 67,71\% menjadi 84,69\%, dan disebabkan pula oleh meningkatnya penerimaan Lain-lain Pendapatan Asli Daerah yang Sah dari $(92,71) \%$ menjadi $79,08 \% \%$ yang dikarenakan oleh meningkatnya penerimaan dari 
penerimaan lain-lain dari $(99,06) \%$ menjadi $94,23 \%$. Adapun faktor-faktor yang menyebabkan meningkat dan menurunnya lain-lain Pendapatan Asli Daerah yang sah yang merupakan salah satu sumber Pendapatan Asli Daerah yang memberikan pengaruh terhadap besarnya kontribusi Pendapatan Asli Daerah khususnya di Kabupaten Barru selama lima tahun terakhir yaitu tahun 2013-2017 di gambarkan dalam tabel dibawah ini.

Tabel 2. Perkembangan Penerimaan Lain-lain Pendapatan Asli Daerah yang Sah di Kabupaten Barru Tahun 2013-2017.

\begin{tabular}{|c|c|c|c|c|c|c|c|c|c|}
\hline $\begin{array}{l}\text { Pendapatan } \\
\text { Asli Daerah }\end{array}$ & 2013 & 2014 & $\begin{array}{l}\text { Per } \\
\text { kem } \\
\text { ban } \\
\text { gan } \\
\%\end{array}$ & 2015 & $\begin{array}{l}\text { Per } \\
\text { kem } \\
\text { ban } \\
\text { gan } \\
\%\end{array}$ & 2016 & $\begin{array}{l}\text { Per } \\
\text { kem } \\
\text { ban } \\
\text { gan } \\
\%\end{array}$ & 2017 & $\begin{array}{l}\text { Per } \\
\text { kem } \\
\text { ban } \\
\text { gan } \\
\%\end{array}$ \\
\hline $\begin{array}{l}\text { Lain-Lain PAD } \\
\text { yang sah }\end{array}$ & $\begin{array}{l}7.275 .678 . \\
674\end{array}$ & $\begin{array}{l}24.347 .779 . \\
613\end{array}$ & $\begin{array}{l}70,1 \\
2\end{array}$ & $\begin{array}{l}12.947 .797 \\
200\end{array}$ & $\begin{array}{l}(46,8 \\
2)\end{array}$ & $\begin{array}{l}943.561 .9 \\
23\end{array}$ & $\begin{array}{l}(92,7 \\
1)\end{array}$ & $\begin{array}{l}4.510 .737 . \\
632\end{array}$ & $\begin{array}{l}79,0 \\
8\end{array}$ \\
\hline Jasa Giro & $\begin{array}{l}510.485 .1 \\
84 \\
\end{array}$ & 355.990 .226 & $\begin{array}{l}30,2 \\
6)\end{array}$ & 448.619 .519 & $\begin{array}{l}20,6 \\
5 \\
\end{array}$ & $\begin{array}{l}458.733 .1 \\
47 \\
\end{array}$ & 2,20 & $\begin{array}{l}705.156 .3 \\
37\end{array}$ & $\begin{array}{l}34,9 \\
5 \\
\end{array}$ \\
\hline $\begin{array}{l}\text { Pengembalian } \\
\text { Dana Bergulir }\end{array}$ & $\begin{array}{l}28.032 .20 \\
0\end{array}$ & 92.338 .000 & $\begin{array}{l}69,6 \\
4 \\
\end{array}$ & 46.150 .000 & $\begin{array}{l}(50,0 \\
2)\end{array}$ & $\begin{array}{l}379.700 .0 \\
00\end{array}$ & $\begin{array}{l}(87,8 \\
5)\end{array}$ & $\begin{array}{l}394.830 .5 \\
50\end{array}$ & 3,83 \\
\hline $\begin{array}{l}\text { Sumbangan } \\
\text { Pihak Ke-3 }\end{array}$ & $\begin{array}{l}14.470 .31 \\
2\end{array}$ & - & $(100)$ & 1.228 .500 & 100 & - & $(100)$ & - & - \\
\hline $\begin{array}{l}\text { Pendapatan } \\
\text { Bunga Deposito }\end{array}$ & $\begin{array}{l}5.397 .215 . \\
173\end{array}$ & $\begin{array}{l}3.791 .493 .0 \\
73\end{array}$ & $\begin{array}{l}(29,7 \\
5)\end{array}$ & $\begin{array}{l}1.819 .484 .5 \\
18\end{array}$ & $\begin{array}{l}(52,0 \\
1)\end{array}$ & 5.128 .776 & $\begin{array}{l}(99,7 \\
2)\end{array}$ & $\begin{array}{l}1.677 .029 . \\
213\end{array}$ & $\begin{array}{l}99,6 \\
9 \\
\end{array}$ \\
\hline $\begin{array}{l}\text { Penerimaan } \\
\text { Lain-Lain }\end{array}$ & $\begin{array}{l}1.325 .475 . \\
805\end{array}$ & $\begin{array}{l}20.200 .296 . \\
314\end{array}$ & $\begin{array}{l}93,4 \\
4\end{array}$ & $\begin{array}{l}10.632 .314 . \\
663\end{array}$ & $\begin{array}{l}(47,3 \\
7)\end{array}$ & $\begin{array}{l}100.000 .0 \\
00\end{array}$ & $\begin{array}{l}(99,0 \\
6)\end{array}$ & $\begin{array}{l}1.733 .721 . \\
532\end{array}$ & $\begin{array}{l}94,2 \\
3\end{array}$ \\
\hline
\end{tabular}

Sumber: Badan Pengelolah Keuangan Daerah Kabupaten Barru

Berdasarkan tabel diatas dapat dilihat bahwa dari tahun 2013 ke tahun 2014 terjadi peningkatan penerimaan yang sangat drastis hal ini disebabkan oleh adanya penerimaan yang sangat besar dari Penerimaan lain-lain sebesar 93,44\% serta Penerimaan Dana Bergulir sebesar 69,64\%. Namun di sisi lain, Penerimaan Jasa Giro menurun sebesar $30,26 \%$ dan Pendapatan Bunga Deposito juga menurun sebesar 29,75\% sedangkan untuk Sumbangan Pihak ke tiga tidak ada penerimaan sama sekali. Hasil Pengelolaan Kekayaan Daerah yang Dipisahkan adapun hal-hal yang menyebakan perkembangan penerimaan Hasil Pengelolaan Kekayaan Daerah yang dipisahkan naik turun dapat dilihat pada tabel dibawah ini. 
Sentralisasi Volume 8 (1) : Hal 18 - 32 | 2019 kontribusi pajak daerah dan retribusi daerah... DOl: https://doi.org/10.33506/sl.v8i1.384

A.Imam Zulfikar

Tabel 3. Perkembangan Penerimaan Hasil Pengelolaan Kekayaan Daerah yang dipisahkan di Kabupaten Barru Tahun 2013-2017.

\begin{tabular}{|c|c|c|c|c|c|c|c|c|c|}
\hline $\begin{array}{l}\text { Pendapatan } \\
\text { Asli Daerah }\end{array}$ & 2013 & 2014 & $\begin{array}{l}\text { Perke } \\
\text { mban } \\
\text { gan } \\
\%\end{array}$ & 2015 & $\begin{array}{l}\text { Perke } \\
\text { mban } \\
\text { gan } \\
\%\end{array}$ & 2016 & $\begin{array}{l}\text { Perke } \\
\text { mban } \\
\text { gan } \\
\%\end{array}$ & 2017 & $\begin{array}{l}\text { perke } \\
\text { mban } \\
\text { gan } \\
\%\end{array}$ \\
\hline $\begin{array}{l}\text { Hasil } \\
\text { Pengelolaan } \\
\text { Kekayaan } \\
\text { Daerah yang } \\
\text { dipisahkan }\end{array}$ & $\begin{array}{l}2.104 .900 .00 \\
0\end{array}$ & $\begin{array}{l}2.682 .696 .22 \\
5\end{array}$ & 21,54 & $\begin{array}{l}3.375 .011 .50 \\
1\end{array}$ & 20,51 & $\begin{array}{l}3.866 .382 .11 \\
2\end{array}$ & 30,61 & $\begin{array}{l}4.536 .188 .44 \\
9\end{array}$ & 14,77 \\
\hline Bank BPD & $\begin{array}{l}2.064 .900 .00 \\
0\end{array}$ & $\overline{-1}$ & (100) & $\overline{-1}$ & $\overline{-1}$ & $\begin{array}{l}3.866 .382 .11 \\
2\end{array}$ & 100 & - & (100) \\
\hline Laba BUMN & - & $\begin{array}{l}2.682 .696 .22 \\
6\end{array}$ & 100 & $\begin{array}{l}3.375 .011 .50 \\
1\end{array}$ & 20,51 & - & $(100)$ & $\begin{array}{l}4.536 .188 .44 \\
9\end{array}$ & 100 \\
\hline Laba BUMD & - & - & - & - & - & - & - & - & - \\
\hline $\begin{array}{l}\text { Perusahaan } \\
\text { Setya Karya }\end{array}$ & 40.000 .000 & - & $(100)$ & - & - & - & - & - & - \\
\hline
\end{tabular}

Sumber: Badan Pengelolah Keuangan Daerah Kabupaten Barru

Berdasarkan pada tabel diatas dapat dilihat bahwa penerimaan Hasil Pengelolaan Kekayaan Daerah yang Dipisahkan dari tahun ke tahun terus mengalami peningkatan, terbukti pada tahun 2013 ke tahun 2014 terjadi peningkatan sebesar $21,54 \%$ hal ini disebabkan oleh adanya penerimaan pada Laba BUMN yang dari tahun lalu tidak ada sama sekali namun di sisi lain Bank BPD, Laba BUMD, serta Perusahaaan Setya Karya tidak ada penerimaan sama sekali di tahun berikutnya yaitu tahun 2014. Adapun yang menyebabkan terjadinya hal-hal tersebut yaitu dapat dilihatt pada tabel 5 sebagai berikut.

Tabel 4. Perkembangan Penerimaan Pajak Daerah di Kabupaten Barru Tahun 20132017.

\begin{tabular}{|c|c|c|c|c|c|c|c|c|c|}
\hline Uraian & 2013 & 2014 & $\begin{array}{l}\text { Perkem } \\
\text { bangan } \\
\%\end{array}$ & 2015 & $\begin{array}{l}\text { Perkem } \\
\text { bangan } \\
\%\end{array}$ & 2016 & $\begin{array}{l}\text { Perkem } \\
\text { bangan } \\
\%\end{array}$ & 2017 & $\begin{array}{l}\text { Perkem } \\
\text { bangan } \\
\%\end{array}$ \\
\hline Pajak Daerah & $\begin{array}{r}1.100 .295 .46 \\
5\end{array}$ & 229.175 .910 & $(79,17)$ & $\begin{array}{l}2.543 .376 .01 \\
6\end{array}$ & 90,98 & $\begin{array}{l}2.664 .312 .64 \\
4\end{array}$ & 4,54 & 2.696 .292 .388 & 1,19 \\
\hline Pajak Hotel & 1.494 .000 & 1.328 .000 & $(11,11)$ & 1.826 .000 & 27,27 & 2.208 .000 & 17,30 & 4.426 .000 & 50,11 \\
\hline Pajak Restoran & 20.175 .000 & 16.335 .000 & $(19,03)$ & 27.895 .000 & 41,44 & 28.615 .000 & 2,25 & 32.715 .000 & 12,53 \\
\hline Pajak Hiburan & 400.000 & 1.600 .000 & 75 & 714.000 & $(35,38)$ & 100.000 & $(85,99)$ & 1.000 .000 & 90 \\
\hline Pajak Reklame & 7.510 .500 & 10.240 .250 & 26,66 & 8.810 .000 & $(13,96)$ & 4.340 .000 & $(50,74)$ & 20.625 .500 & 78,99 \\
\hline Pajak Penerangan Jalan & $\begin{array}{l}1.070 .715 .96 \\
5\end{array}$ & 120.207 .060 & $(88,77)$ & $\begin{array}{l}1.427 .467 .16 \\
0\end{array}$ & 91,58 & $\begin{array}{l}1.671 .383 .01 \\
9\end{array}$ & 14,59 & 1.703 .090 .434 & 1,86 \\
\hline Pajak Galian Gol.C & - & 79.465 .600 & 100 & $\begin{array}{l}1.076 .663 .85 \\
6\end{array}$ & 92,62 & 957.666 .625 & $(11,05)$ & 727.520 .477 & $(24,03)$ \\
\hline
\end{tabular}


Sumber: Badan Pengelolah Keuangan Daerah Kabupaten Barru

Berdasarkan pada tabel di atas maka dapat disimpulkan bahwa sumber penerimaan Pajak Daerah di Kabupaten Barru tahun 2013-2017 yang meliputi Pajak Hotel, Pajak Restoran, Pajak Hiburan, Pajak Reklame, Pajak Penerangan Jalan, dan Pajak Galian Gol.C, serta Pajak BPHTB mengalami fluktuasi, hal ini menunjukkan bahwa Pemerintah Daerah harus lebih bekerja keras untuk meningkatkan penerimaan Pajak Daerah dengan memperbaiki system administrasi perpajakan dan meningkatkan pengawasan terhadap pembayaran pajak serta merekrut atau mempekerjakan petugas pajak yang telah diseleksi dengan kriteria tertentu dan memiliki loyalitas yang tinggi dan kejujuran serta kedisiplinan yang juga merupakan indikator penilaian utama terlepas dari hal tersebut pemerintah juga sebaiknya memberikan sosialisasi tentang pajak agar pemahaman masyarakat lebih terarah sehingga dapat meningkatkan kepatuhan para Wajib Pajak untuk membayarkan Pajak terutangnya sebagaimana mestinya.

Perkembangan penerimaan sumber-sumber Pendapatan Asli Daerah pada tabel 2 maka berikut ini disajikan besarnya kontribusi dari masing-masing sumber penerimaan Pendapatan Asli Daerah seperti yang disajikan pada tabel dibawah ini.

Tabel 5. Kontribusi Lain-lain Pendapatan Asli daerah yang Sah terhadap Pendapatan Asli Daerah di Kabupaten Barru pada tahun 2013-2017.

\begin{tabular}{clll}
\hline Tahun & $\begin{array}{l}\text { Lain-lain } \\
\text { Pendapatan Asli } \\
\text { Daerah yang Sah }\end{array}$ & $\begin{array}{l}\text { Pendapatan Asli } \\
\text { daerah }\end{array}$ & $\begin{array}{l}\text { Kontribusi Lain-lain } \\
\text { Pendapatan Asli } \\
\text { Daerah yang Sah } \\
\text { Terhadap Pendapatan } \\
\text { Asli Daerah }\end{array}$ \\
\hline 2013 & 7.275 .682 .674 & 12.148 .399 .432 & $59,89 \%$ \\
\hline 2014 & $\mathbf{2 4 . 3 4 7 . 7 7 9 . 6 1 3}$ & $\mathbf{2 8 . 6 7 1 . 7 6 3 . 6 8 7}$ & $\mathbf{8 4 , 9 2 \%}$ \\
\hline 2015 & 12.947 .797 .200 & 20.764 .458 .176 & $62,36 \%$ \\
\hline 2016 & $\mathbf{9 4 3 . 5 6 1 . 9 2 3}$ & $\mathbf{9 . 9 0 5 . 2 2 6 . 7 3 4}$ & $\mathbf{9 , 5 3 \%}$ \\
\hline 2017 & 4.510 .737 .632 & 17.883 .781 .964 & $25,22 \%$ \\
\hline Rata & rata kontribusi & cukup besar & $\mathbf{4 8 , 3 8 \%}$ \\
\hline \multicolumn{5}{c}{ Sumber: Badan Pengelolah Keuangan Daerah Kabupaten Barru }
\end{tabular}


Berdasarkan tabel diatas dapat dilihat bahwa penerimaan Lain-lain Pendapatan Asli Daerah yang Sah dari tahun ketahun mengalami fluktuasi sehingga persentase kontribusinya juga mengalami fluktuasi, adapun hal-hal yang menyebabkan terjadinya hal demikian yaitu telah dijelaskan pada tabel 6 .

Tabel 6. Kontribusi Hasil Pengelolaan Kekayaan Daerah yang dipisahkan terhadap Pendapatan Asli Daerah di Kabupaten Barru pada tahun 20132017.

\begin{tabular}{llll}
\hline Tahun & $\begin{array}{l}\text { Hasil Pengelolaan } \\
\text { Kekayaan Daerah } \\
\text { yang dipisahkan }\end{array}$ & $\begin{array}{l}\text { Pendapatan Asli } \\
\text { daerah }\end{array}$ & $\begin{array}{l}\text { Kontribusi Hasil Pengelolaan } \\
\text { Kekayaan Daerah yang } \\
\text { dipisahkan Terhadap } \\
\text { Pendapatan Asli Daerah }\end{array}$ \\
\hline 2013 & 2.104 .900 .000 & 12.148 .399 .432 & $17,33 \%$ \\
\hline 2014 & $\mathbf{2 . 6 8 2 . 6 9 6 . 2 2 6}$ & $\mathbf{2 8 . 6 7 1 . 7 6 3 . 6 8 7}$ & $\mathbf{9 , 3 6 \%}$ \\
\hline 2015 & 3.375 .011 .501 & 20.764 .458 .176 & $16,25 \%$ \\
\hline 2016 & $\mathbf{3 . 8 8 6 . 3 8 2 . 1 1 2}$ & $\mathbf{9 . 9 0 5 . 2 2 6 . 7 3 4}$ & $\mathbf{3 9 , 2 4 \%}$ \\
\hline 2017 & 4.536 .188 .449 & 17.883 .781 .964 & $25,36 \%$ \\
\hline & Rata-rata kontribusi & cukup & $\mathbf{2 1 , 5 1 \%}$ \\
\hline
\end{tabular}

Sumber : Badan Pengelolah Keuangan Daerah Kabupaten Barru

Penerimaan Hasil Pengelolaan Kekayaan Daerah yang dipisahkan dari tahun ke tahun terus mengalami peningkatan kecuali ditahun 2014 yang mengalami sedikit penurunan. Sumber Penerimaan Pendapatan Asli Daerah yang lain yaitu Pajak Daerah. Sumber penerimaan ini merupakan sumber penerimaan yang sangat berpotensi jika dikelolah dengan baik oleh Pemerintah daerah setempat.

\section{Simpulan}

Dari hasil analisis yang telah dikemukakan pada bab sebelumnya, maka penulis menarik kesimpulan sebagai berikut (1) Dari hasil analisis persentase Kontribusi Pajak Daerah terhadap Pendapatan Asli Daerah di Kabupaten Barru dari tahun 2013-2017 tergolong kecil dengan nilai persentase 12,82\%. (2) Sedangkan hasil analisis persentase Kontribusi Retribusi Daerah terhadap Pendapatan Asli Daerah di Kabupaten Barru dari tahun 2013-2017 tergolong kecil dengan nilai persentase 17,34\%. (3) Berdasarkan hasil analisis persentase Kontribusi Pajak 


\section{Sentralisasi Volume 8 (1) : Hal 18 - 32 | 2019}

kontribusi pajak daerah dan retribusi daerah... DOI: https://doi.org/10.33506/sl.v8i1.384

A.Imam Zulfikar

Daerah dan Retribusi Daerah terhadap Pendapatan Asli Daerah di Kabupaten Barru dari tahun 2013-2017 tergolong cukup dengan nilai persentase 30,06\%. (4) Berdasarkan hasil analisis persentase bahwa dari ke empat sumber Pendapatan Asli Daerah, Lain-lain Pendapatan Asli Daerah yang Salah yang mempunyai kontribusi yang cukup besar terhadap Pendapatan Asli Daerah dengan persentase sebesar $48,38 \%$ dan memiliki perkembangan yang baik dengan rata-rata perkembangan yaitu 72,20\% yang tergolong besar, adapun yang mempunyai kontribusi yang kecil yaitu Pajak Daerah dengan persentase $12,82 \%$ dan rata-rata perkembangannya sebesar $43,97 \%$ yang tergolong cukup besar, serta kontribusi Retribusi sebesar $17,34 \%$ dengan rata-rata perkembangan sebesar 30,81\% yang tergolong cukup.

\section{Saran}

Berdasar dari kesimpulan di atas maka penulis mencoba memberikan saransaran yaitu sebagai berikut (1) Dengan melihat jumlah dan persentase serta perkembangan penerimaan Pajak Daerah yang masih tergolong kecil dan Retribusi Daerah juga yang masih tergolong kecil, maka sebaiknya pemerintah daerah lebih memperhatikan dan mengembangakan sumber-sumber penerimaan Pajak Daerah dan Retribusi Daerah. Dimana penerimaan dari Pajak Hiburan masih sangat kecil begitupun halnya dengan penerimaan dari Pajak Galian Gol. C yang dari tahun 2010 mengalami penurunan. Sedangkan penerimaan dari Retribusi Daerah juga mengalami hal yang sama dimana sumber penerimaannya masih sangat kecil yaitu dari penerimaan Retribusi Rekreasi yang masih kecil dan tidak mengalami peningkatan dari tahun 2010, begitupun halnya dengan penerimaan Retribusi Pemakain Kekayaan Daerah dan Retribusi Ketatausahaan yang mengalami penurunan. (2) Sebaiknya pemerintah meningkatkan peenerimaan Pajak Hiburan dengan menyediakan fasilitas ataupun dengan merenovasi dan memperbaiki tata kota agar masyarakat juga tertarik mengadakan pagelaran, pameran ataupun pertandingan, yang selama ini masih sangt jarang ditemui di Kabupaten Barru. Sedangkan untuk meningkatkan Retribusi Daerah misalnya Retribusi Rekreasi, 


\section{Sentralisasi Volume 8 (1) : Hal 18 - 32 | 2019 kontribusi pajak daerah dan retribusi daerah... DOI: https://doi.org/10.33506/sl.v8i1.384}

dimana masih banyak tempat Rekreasi di Kabupaten Barru yang mempunyai nilai seni dan nilai jual tinggi yang belum terekspos dan tak kalah menarik dengan tempat Rekreasi yang ada di Kabupaten Lainnya.

\section{Daftar Pustaka}

Adyabarata, Asep. Bambang Trihartanto. 2005. Pemeriksaan Keuangan Negara/Daerah. Jakarta: PT. Elex Media Komputindo.

Boediono, B. 2001. Perpajakan Indonesia. Diadit Media. Jakarta.

Brotodihardjo, R. Santoso. 2003. Pengantar Ilmu Hukum Pajak. Bandung : Refika Aditama

Fauziah, Ahmad Iskandar. 1982. Cara Membaca Situasi Anggaran Pendapatan Belanja Daerah. Malang: Universitas Brawijaya.

Faisal, Gatot S.M. 2009. How To Be A Smarter Tax Payer Bagaimana Menjadi Wajib Pajak. Jakarta: Grasindo.

Kaho, Josef Riwu. 2005. Prospek Otonomi Daerah di Negara Republik Indonesia. Jakarta: Raja Grafindo Persada

Lukas,Setia Atmaja. 2009. Statistika untuk bisnis dan ekonomi. Yogyakarta : Andi offset.

Liberti, Pandiangan. 2002. Pemahaman Praktis Undang-Undang Perpajakan Indonesia. Jakarta: Erlangga.

Mardiasmo. 2002. Otonomi dan Manajemen Keuangan Daerah . Yogyakarta : Andi Offset.

Mardiasmo. 2009. Perpajakan - Edisi revisi 2009. Yogyakarta : Andi Offset.

Mardiasmo. 2011. Perpajakan - Edisi revisi 2009. Yogyakarta : Andi Offset.

S.Budi, Purnomo. 2009. Obligasi Daerah. Bandung: Alfabeta.

Suandy, Erly. 2002. Perpajakan, Jakarta: Penerbit PT. Salemba Empat Patria.

Supriatna, Tjahya. 1996. Sistem Administrasi Pemerintah di Daerah. Jakarta: Bumi Aksara. 


\section{Sentralisasi Volume 8 (1) : Hal 18 - 32 | 2019}

kontribusi pajak daerah dan retribusi daerah... DOI: https://doi.org/10.33506/sl.v8i1.384

A.Imam Zulfikar

Siahaan, Marihot P. 2005. Pajak Daerah dan Retribusi Daerah. Jakarta . PT. Raja Grafindo Persada.

Sudjana. 2001. Metode Statistika. edisi keenam. Bandung: Tarsito

Sugiyono. 2009. Statistika Untuk Penelitian, cetak ke-empat belas. Bandung : CV. Alvabeta.

Sugianto,dkk. 2007. Ekonomi mikro sebuah kajian konfrehensif, Jakarta : PT. Gramedia Pustaka Utama.

Sugianto. 2007. Pajak dan Retribusi Daerah (Pengelolaan Pemerintah Daerah dalam Aspek Keuangan Pajak dan Retribusi Daerah). Jakarta: Grasindo.

Sutrisno Hadi. 2000. Bimbingan Menulis Skripsi dan Thesis. Yogyakarta : Penerbit Andi Offset.

Waluyo. 2002. Perpajakan Indonesia. Jakarta: Penerbir Salemba Empat.

Waluyo. 2008. Perpajakan Indonesia. Jakarta: Penerbir Salemba Empat.

Widjaja Aw. 1992. Titik Berat Otonomi Daerah Tingkat II. Jakarta : Rajawali Pers.

Widjaya. 2004. Otoda dan Daerah Otonomi. Jakarta : PT. Raja Grafindo Perdasa.

Yani, Ahmad. 2002. Hubungan Keuangan Antara Pemerintah Pusat dan Daerah di Indonesia. Jakarta: PT. Raja Grafindo Persada.

\section{PERUNDANG-UNDANGAN :}

Undang-Undang Pajak Daerah dan Retribusi Daerah 2009. 2010. Jakarta : Pustaka Yustisia.

Undang-Undang RI Nomor 33 Tahun 2004, Tentang Perimbangan Keuangan antara Pemerintah Pusat dengan Pemerintah Daerah.

Undang-Undang Nomor 34 Tahun 2000, Tentang Perubahan Atas Undang-Undang Republik Indonesia Nomor 18 Tahun 1997 Tentang Pajak Pajak Daerah Dan Retribusi Daerah

Peraturan Daerah Kabupaten Barru Tingkat II No.8 Tahun 1998 tentang Pajak Hotel dan Restoran.

Peraturan Daerah Kabupaten Barru Tingkat II No.9 Tahun 1998 tentang Pajak Hiburan. 


\section{Sentralisasi Volume 8 (1) : Hal 18 - 32 | 2019}

kontribusi pajak daerah dan retribusi daerah... DOI: https://doi.org/10.33506/sl.v8i1.384

A.Imam Zulfikar

Peraturan Daerah Kabupaten Barru Tingkat II No.6 Tahun 1998 tentang Pajak Reklame.

Peraturan Daerah Kabupaten Barru Tingkat II No.7 Tahun 1998 tentang Pajak Penerangan Jalan.

\section{SUMBER LAIN}

Achmad Lutfi, 2006, "Penyempurnaan Administrasi Pajak Daerah dan Retribusi Daerah : Suatu upaya dalam optimalisasi penerimaan PAD”, Jurnal Ilmu Administrasi dan Organisasi : Bisnis \& Birokrasi, Volume XIV, Nomor 1, Januari 2006, Departemen Ilmu Administrasi, Fakultas Ilmu Sosial dan Ilmu Politik, Universitas Indonesia. http://staff.ui.ac.id. Diunduh 17 oktober 2011 (pukul 20:22)

Diza, Mohm Rangga. 2009 . Kontribusi Pajak Daerah dan Retribusi Daerah terhadap Pendapatan Asli Daerah Di Proponsi Sumatra Utara. Depertemen S1 Akuntansi, Fakultas Ekonomi : Universitas Sumatra Utara. http://respository. usu.ac.id. diunduh 9 september 2011 (pukul 12:30) 